\title{
Head loss in laser-perforated thin-walled polyethylene pipes for irrigation
}

\author{
Verônica G. M. L. de Melo ${ }^{1}$, José A. Frizzone, Antonio P. de Camargo² \& Wagner W. Á. Bombardelli ${ }^{1}$ \\ ${ }^{1}$ Universidade de São Paulo/Escola Superior de Agricultura “Luiz de Queiroz”. Piracicaba, SP, Brasil. E-mail: veronica.martins@usp.br - ORCID: 0000- \\ 0003-0665-3726; frizzone@usp.br - ORCID: 0000-0002-4251-1496; wavila@usp.br - ORCID: 0000-0002-5939-5524 \\ ${ }^{2}$ Universidade Estadual de Campinas/Faculdade de Engenharia Agrícola. Campinas, SP, Brasil. E-mail:antonio.camargo@feagri.unicamp.br (Corresponding \\ author) - ORCID: 0000-0001-5164-2634
}

\begin{abstract}
For reducing fixed and operational costs in pressurized irrigation systems, thin-walled polyethylene pipes with laser-perforated orifices are manufactured to operate under low pressure (up to $100 \mathrm{kPa}$ ). Hydraulic characterization of these materials is essential for designing irrigation systems. Considering the material elasticity and the thin wall thickness (about $200 \mu \mathrm{m}$ ), the internal diameter of these pipes may vary according to the operating pressure, resulting in changes of head losses. The purpose of this study was to analyze the head loss in flexible pipes with laser-perforated orifices, and to estimate the maximum length of laterals based on criteria of water distribution uniformity. Non-perforated pipe samples were tested to obtain equations of friction loss. Equations were fitted as a function of flow rate and pressure head at the pipe inlet, and, alternatively, the Darcy-Weisbach equation was modified considering the diameter expressed as a power-law function of pressure head. The equation of head loss as a function of flow rate and pressure head provided proper estimations and considered effects related to changes in the diameter of plastic pipes due to variations in the pressure head. The Darcy-Weisbach equation can be employed for estimating head loss in flexible pipes, whose diameter varies due to pressure, but the diameter must be calculated as a function of the pressure head at the lateral inlet.
\end{abstract}

Key words: operating pressure, diameter change, design, lateral line

\section{Perda de carga em tubos de polietileno de parede fina para irrigação perfurados a laser}

RESUMO: Para reduzir custos fixos e operacionais em sistemas de irrigação pressurizados são produzidos tubos de polietileno com pequena espessura de parede, com orifícios de descarga perfurados a laser, que operam a baixas pressões (até $100 \mathrm{kPa}$ ). A caracterização hidráulica desses materiais é essencial para o dimensionamento dos sistemas de irrigação. Dada a elasticidade do material de fabricação e a fina espessura de parede (aproximadamente $200 \mu \mathrm{m}$ ) dos tubos, o diâmetro interno pode ser alterado em função da pressão de operação, provocando variações na perda de carga. $\mathrm{O}$ objetivo deste trabalho foi analisar a perda de carga em tubos de polietileno flexíveis perfurados a laser e expressar o comprimento máximo dessas tubulações em função de critérios de uniformidade de distribuição de água. Utilizaram-se amostras de tubos não perfurados para determinar as equações de perda de carga. Ajustaram-se equações em função da vazão e da carga de pressão na entrada do tubo e, alternativamente, ajustou-se a equação de Darcy-Weisbach, com o diâmetro expresso em função da carga de pressão por um modelo potencial. A equação de perda de carga em função da vazão e da carga de pressão fornece estimativas adequadas e inclui efeitos de variação do diâmetro dos tubos plásticos devido a variações na carga de pressão. A equação de Darcy-Weisbach pode ser utilizada para o cálculo da perda de carga em tubos flexíveis, cujo diâmetro varia com a pressão, desde que o diâmetro seja expresso por uma função da pressão de entrada da lateral.

Palavras-chave: pressão de operação, variação do diâmetro, dimensionamento, linha lateral 


\section{INTRODUCTION}

The design of irrigation laterals uses criteria to achieve high uniformity of water distribution (Perboni et al., 2015). For pipes with fixed diameter, the objective in the project is to determine the maximum length of the pipe. Usually, the designers of the irrigation system utilize head loss equations existing in the literature, considering the internal diameters of the pipes informed by the manufacturers. Thin-walled polyethylene pipes with laser-perforated orifices are produced with flexible plastic materials, and their diameter may change due to pressure variations along the lateral line (Andrade, 1990; Vilela et al., 2003; Provenzano et al., 2016). Such alteration of diameter influences the head loss and may lead to alterations in the hydraulic conditions of the system.

Frizzone et al. (1998) studied head loss in thin-walled flexible polyethylene drip tapes and demonstrated variation in pipe diameter and head loss with inlet pressure and its influence on the calculation of the maximum length of the lateral line. Considering the importance of the variation in the diameter of polyethylene pipes as a function of the operating pressure, Rettore Neto et al. (2014) developed a model to determine head loss along elastic pipes, introducing in the universal equation the elasticity modulus of the material used to manufacture the pipe.

This study aimed to analyze head loss in thin-walled flexible polyethylene pipes, with laser-perforated orifices, and express the maximum length of these pipes as a function of criteria of water distribution uniformity.

\section{Material ANd Methods}

The study was conducted at the Laboratory of Irrigation of the "Luiz de Queiroz" College of Agriculture, University of São Paulo (Piracicaba, SP, Brazil). Tests were conducted with the Santeno I model to determine head loss in the flexible pipe without orifices. Rolls of this material without orifices were obtained with the manufacturer. The Santeno I model is a low-density linear polyethylene pipe, manufactured from virgin raw material, with discharge orifices perforated by laser. According to the manufacturer, this pipe produces micro-jets of water aimed upwards ( $85^{\circ}$ relative to soil surface), irrigated a $2.5 \mathrm{~m}$ strip, with the following technical characteristics: service pressure from 20 to $80 \mathrm{kPa}, 0.15 \mathrm{~m}$ distance between pairs of emitters, orifice diameter of $0.30 \mathrm{~mm}$, pipe nominal diameter of $0.028 \mathrm{~m}$, wall thickness of $200 \mu \mathrm{m}$ (8 mil) and micro-jets with height of $1.80 \mathrm{~m}$.

The experimental procedures to determine the continuous head loss were carried out using an automated test bench, developed and validated by Bombardelli et al. (2017). The tests were conducted at the laboratory using $22 \mathrm{~m}$ of flexible pipe without orifices. Test pressures were created by a motor pump equipped with a frequency inverter and ProportionalIntegral-Derivative (PID) controller. In addition, the bench has a micro-controlled electronic circuit managed by a supervisory application, and this system was used to acquire data of sensors and control the process related to the tests. The bench was validated based on stability tests and charts used in statistical process control (Bombardelli et al., 2017).
Head loss equations were obtained for the inlet pressures of 49.0, 58.8, 68.6, 78.4, 88.2 and $98 \mathrm{kPa}$. For each test pressure, head loss was obtained with increasing and decreasing flow rates, at increments of $0.2 \mathrm{~m}^{3} \mathrm{~h}^{-1}$. Twenty pairs of flow ratepressure values were defined in each cycle of test. Thus, curves relating flow rate-head loss were fitted with 40 pairs of values for each inlet pressure. To ensure accuracy and stability in the control of test pressures, the pressure control system operated in closed loop using PID control. Flow rate was monitored using an electromagnetic flow rate meter, brand Krohne; model IFC $010 \mathrm{D}$, with resolution of $1 \times 10^{-2} \mathrm{~m}^{3} \mathrm{~h}^{-1}$, flow rate range from 0 to $4 \mathrm{~m}^{3} \mathrm{~h}^{-1}$ and expanded uncertainty of $0.5 \%$ of the full-scale range (FSR). This instrument was installed upstream the evaluated pipe. The pressure drop caused by the flowing through the pipe was measured by a differential pressure transmitter, brand Novus, model $\mathrm{NP} 800 \mathrm{H}$, with resolution of $1 \times 10^{-2} \mathrm{kPa}$, measurement range of $1-100 \mathrm{kPa}$, accuracy of $0.075 \%$ informed by the manufacturer.

Water temperature was monitored by a temperature transmitter, brand Zürich ${ }^{\oplus}$, model TZD 420, with resolution of $0.1^{\circ} \mathrm{C}$, measurement range between 0 and $50^{\circ} \mathrm{C}$, measurement uncertainty of $0.5 \%$ FSR. During the tests, the mean water temperature was $25^{\circ} \mathrm{C}$ with mean variation range of $\pm 2{ }^{\circ} \mathrm{C}$. The correction of the water density as a function of temperature, specified for the atmospheric pressure of $101.3 \mathrm{kPa}$ and gravitational acceleration of $9.807 \mathrm{~m} \mathrm{~s}^{-2}$, was performed according to Tanaka et al. (2001). At $25^{\circ} \mathrm{C}$, water density is $997.0 \mathrm{~kg} \mathrm{~m}^{-3}$ and its dynamic viscosity is $8.903 \times 10^{-4} \mathrm{~N} \mathrm{~s} \mathrm{~m}^{-2}$, whose ratio results in the kinematic viscosity of $0.893 \times 10^{-6} \mathrm{~m}^{2} \mathrm{~s}^{-1}$.

The general equation to calculate unit head loss in circularsection pressurized pipes, for uniform permanent flow, can be synthesized by Eq. 1 (Swamee \& Swamee, 2007):

$$
\mathrm{J}=\mathrm{k}_{1} \frac{\mathrm{Q}^{\mathrm{m}}}{\mathrm{D}^{\mathrm{n}}}
$$

where:

J - unit head loss of the flow, $\mathrm{m} \mathrm{m}^{-1}$;

Q - flow rate in the pipe, $\mathrm{m}^{3} \mathrm{~s}^{-1}$;

D - pipe internal diameter, $\mathrm{m}$;

$\mathrm{k}_{1} \quad$ - combined coefficient of units and roughness for a particular formula of head loss;

$\mathrm{m}$ - exponent of velocity or flow rate for a particular formula of head loss $(\mathrm{m}=1$ for laminar flow and $\mathrm{m}=2$ for full turbulent flow in the Darcy-Weisbach equation); and,

$\mathrm{n} \quad$ - exponent of internal diameter in the head loss equation ( $\mathrm{n}=4$ for laminar flow and $\mathrm{n}=5$ for full turbulent flow in the Darcy-Weisbach equation). Generally $n=m+3$.

Considering pipe diameter as constant, the relations between flow rate and head loss were studied for each one of the six inlet pressures. Regression analysis was used to fit empirical equations of unit head loss as a function of flow rate, in the power-law form (Eq. 2):

$$
\mathrm{J}=\mathrm{k}_{2} \mathrm{Q}^{\mathrm{m}}
$$


where:

$\mathrm{J} \quad$ - unit head loss, $\mathrm{m} \mathrm{m}^{-1}$;

Q - flow rate in the pipe, $\mathrm{m}^{3} \mathrm{~s}^{-1}$;

$\mathrm{k}_{2} \quad$ - regression constant depending on the studied pipe; and,

$\mathrm{m}$ - regression constant depending on flow regime.

Assuming that pipe diameter (D) increases with the pressure head at the pipe inlet $\left(\mathrm{H}_{\mathrm{o}}\right)$, according to a power-law model $\left(\mathrm{D}=\mathrm{C} \mathrm{H}_{\mathrm{o}} \mathrm{p}\right)$, and that the head loss $(\mathrm{J})$ decreases as the diameter increases, an equation of head loss for the uniform permanent flow was fitted, in the form of Eq. 3:

$$
\mathrm{J}=\mathrm{aQ}^{\mathrm{m}} \mathrm{H}_{0}^{-\mathrm{s}}
$$

where:

$\mathrm{J} \quad$ - unit head loss in the pipe, $\mathrm{m} \mathrm{m}^{-1}$;

$\mathrm{Q}$ - flow rate in the pipe, $\mathrm{m}^{3} \mathrm{~h}^{-1}$;

$\mathrm{H}_{0} \quad$ - pressure head at the pipe inlet, mwc;

$s \quad$ - coefficient expressing the effect of inlet pressure on the pipe internal diameter $(s=n p)$;

$\mathrm{p}$ - empirical exponent of $\mathrm{H}_{0}$ in the power-law model for estimating $\mathrm{D}$ as a function of $\mathrm{H}_{0}$;

$\mathrm{m}$ - exponent of the flow rate characterizing the flow regime;

a - coefficient of adjustment for a particular pipe ( $\mathrm{a}=$ $\left.\mathrm{k}_{1} \mathrm{c}^{-\mathrm{n}}\right)$; and,

c - coefficient of proportionality in the power-law model for estimating $\mathrm{D}$ as a function of $\mathrm{H}_{0}$.

A lateral line of irrigation has lateral outlets and the flow is spatially variable and permanent. Since the flow rate along the lateral is continually reduced with distance (or at each derivation), the head loss also decreases. To calculate head loss in the pipe with continuous flow rate distribution, it is common to use a head loss factor (F), approximated by Eq. 4 (Yildirim \& Ağiralioğlu, 2004; Pinto et al., 2014), in which $\alpha$ is a parameter that expresses the concept of non-uniform flow rate from the laterals along the pipe and $\mathrm{m}$ is the flow rate exponent, which varies according to the head loss equation used. In the studied case, it is reasonable to assume $\alpha=1$, because the number of lateral outlets, spaced by $0.15 \mathrm{~m}$, is very high and it is supposed that, for an acceptable low variation of flow rate along the lateral, the distributed flow rate can be considered as constant.

$$
\mathrm{F}=\frac{1}{\alpha \mathrm{m}+1}
$$

Head loss $\left(h_{\mathrm{f}}, \mathrm{mwc}\right)$ along a lateral line of irrigation with length $\mathrm{L}(\mathrm{m})$ can be calculated by Eq. 5 .

$$
\mathrm{h}_{\mathrm{f}}=\mathrm{aQ}^{\mathrm{m}} \mathrm{H}_{0}^{-\mathrm{s}} \mathrm{FL}
$$

The variables that describe the flow in a pipe are: flow rate, $\mathrm{Q}\left(\mathrm{m}^{3} \mathrm{~s}^{-1}\right)$; pipe internal diameter, $\mathrm{D}(\mathrm{m})$; pipe length $\mathrm{L}$ $(\mathrm{m})$, friction factor $(\mathrm{f})$, which depends on the roughness of the pipe internal surface $\varepsilon(\mathrm{m})$ and on the Reynolds number (R); and head loss $h_{f}(m)$. These variables are related by the
Darcy-Weisbach equation, which combined with the continuity equation, results in Eq. 6 (Lahiouel \& Lahiouel, 2015):

$$
\mathrm{h}_{\mathrm{f}}=\frac{8 \mathrm{fQ} \mathrm{Q}^{2} \mathrm{~L}}{\pi^{2} \mathrm{gD}^{5}}
$$

where:

g - gravitational acceleration, $\mathrm{m} \mathrm{s}^{-2}$; and,

$\mathrm{f} \quad$ - friction factor which depends on $\mathrm{R}$ and $\varepsilon$.

Polyethylene pipes have small roughness $(\varepsilon=8.116 \mu \mathrm{m}$, Rocha et al., 2017) and, given the practical limits of flow velocity adopted in the dimensioning of lateral lines, the predominant flow regime is hydraulically smooth and, consequently, f depends only on R. The Reynolds number, R, is calculated by Eq. 7:

$$
\mathrm{R}=\frac{4 \mathrm{Q}}{\pi \vartheta \mathrm{D}}
$$

where:

$\vartheta$ - kinematic viscosity coefficient of the fluid, $\mathrm{m}^{2} \mathrm{~s}^{-1}$.

For hydraulically smooth turbulent flow, the friction factor $\mathrm{f}$ is generally calculated by the Blasius equation or by similar equations (Eq. 8), specifically obtained for small-diameter polyethylene pipes (Bernuth \& Wilson, 1989; Juana et al., 2002; Provenzano \& Pumo, 2004; Cardoso et al., 2008):

$$
\mathrm{f}=\frac{\mathrm{k}}{\mathrm{R}^{0.25}}
$$

where:

k - constant.

For rigid smooth pipes, Blasius proposed $\mathrm{k}=0.316$. For flexible polyethylene pipes, with wall thicknesses of 150, 200 and $250 \mu \mathrm{m}(6,8$ and $10 \mathrm{mil})$, the studies of Provenzano et al. (2016) indicated $\mathrm{k}=0.285$. Cardoso et al. (2008) indicated $\mathrm{k}=0.300$ for polyethylene pipes of small diameter and wall thickness of $900 \mu \mathrm{m}$ (36 mil).

Comparing the experimental equation of head loss (Eq. 3) with the Darcy-Weisbach equation, with $\mathrm{f}$ expressed by Eq. 8, $\mathrm{k}=0.285, \mathrm{~g}=9.807 \mathrm{~m} \mathrm{~s}^{-2} ; \pi=3.14$ and $\vartheta=0.893 \times 10^{-6} \mathrm{~m}^{2} \mathrm{~s}^{-1}$, leads to Eq. 9:

$$
6.823 \times 10^{-4} \frac{\mathrm{Q}^{1.75}}{\mathrm{D}^{4.75}}=\mathrm{aQ}^{\mathrm{m}} \mathrm{H}_{0}^{-\mathrm{s}}
$$

Eq. 9 was used to estimate the mean equivalent diameter of the pipe $(D, m)$ as a function of pressure head at the pipe inlet $\left(\mathrm{H}_{\mathrm{o}}, \mathrm{m}\right)$ for known flow rates, contained within the interval of the experimental flow rates, and fitting a power-law relation of $\mathrm{D}$ as a function of $\mathrm{H}_{0}$, for $5 \leq \mathrm{H}_{0} \leq 10 \mathrm{~m}$.

Based on the Darcy-Weisbach equation with friction factor f defined by Eq. 9 and diameter expressed as a function of inlet pressure, an equation of continuous head loss in the Santeno pipe was proposed (Eq. 10): 


$$
\mathrm{J}=6.823 \times 10^{-4} \frac{\mathrm{Q}^{1.75}}{\left(\mathrm{cH}_{0}^{\mathrm{p}}\right)^{4.75}}
$$

for $4000 \leq \mathrm{R} \leq 10^{5}$ and $5 \leq \mathrm{H}_{0} \leq 10$ mwc.

The maximum length of the lateral line was calculated using the criterion of maximum flow rate variation. A simple range of variation between maximum and minimum flow rates (Eq. 11) is a relevant uniformity criterion used for a project of lateral line (Wu, 1997; Yildirim, 2007). Values of $10 \%$ or lower are considered as desirable; values from 10 to $20 \%$ are considered as acceptable and values higher than $20 \%$ are unacceptable (Bralts et al., 1987; Sadeghi et al., 2015). For localized irrigation, Frizzone et al. (2012) recommend values of $10 \%$ for an irrigation subunit and $5 \%$ for the lateral line. The maximum flow rate variation allowed in a lateral line corresponds to a maximum variation of pressure head (Eq. 12).

$$
\begin{gathered}
\mathrm{q}_{\mathrm{var}}=\frac{\mathrm{q}_{\max }-\mathrm{q}_{\min }}{\mathrm{q}_{\max }} \\
\mathrm{H}_{\mathrm{var}}=\frac{\mathrm{H}_{\text {max }}-\mathrm{H}_{\min }}{\mathrm{H}_{\max }}
\end{gathered}
$$

where:

$\mathrm{q}_{\text {var }}$ - flow rate variation allowed in the lateral;

$\mathrm{H}_{\mathrm{var}}$ - pressure head variation allowed along the lateral;

$\mathrm{q}_{\max }$ - emitter flow rate under maximum pressure head; and,

$\mathrm{q}_{\text {min }}$ - emitter flow rate under minimum pressure head.

Assuming a power-law model for the relation between flow rate and pressure of the orifices, the relation between $\mathrm{H}_{\mathrm{var}}$ and $\mathrm{q}_{\mathrm{var}}$ is expressed by Eq. 13:

$$
\mathrm{H}_{\mathrm{var}}=1-\left(1-\mathrm{q}_{\mathrm{var}}\right)^{1 / \mathrm{x}}
$$

where:

$\mathrm{x}$ - exponent of orifice flow in the flow rate-pressure relation.

For zero-slope lateral line, the maximum pressure head occurs at the beginning of the line and the minimum head at the end; therefore, the maximum head loss allowed in this line is given by Eq. 14:

$$
\mathrm{h}_{\text {falld }}=\mathrm{H}_{\text {max }}-\mathrm{H}_{\text {min }}
$$

Comparing Eqs. 12 and 14 and substituting $\mathrm{H}_{\max }$ for $\mathrm{H}_{\mathrm{o}}$ results in the head loss allowed in the lateral (Eq. 15):

$$
\mathrm{h}_{\text {falld }}=\mathrm{H}_{\mathrm{var}} \mathrm{H}_{\mathrm{o}}
$$

The mean pressure head $\left(\mathrm{H}_{\text {med }}, \mathrm{m}\right)$ in the zero-slope lateral line is expressed by Eq. 16 (Anyoji \& Wu, 1987):

$$
\mathrm{H}_{\text {mean }}=\mathrm{Ho}-\left(\frac{\mathrm{m}+1}{\mathrm{~m}+2}\right) \mathrm{hf}_{\text {alld }}
$$

where:

$\mathrm{m}$ - exponent of flow rate in the head loss equation.

After knowing the mean pressure head, the mean flow rate of the pairs of orifices $\left(\mathrm{q}_{\text {med }}, \mathrm{m}^{3} \mathrm{~s}^{-1}\right)$ along the lateral was calculated using the flow rate-pressure relation of the pairs of orifices developed by Melo et al. (2017) for Santeno I pipe: $\mathrm{q}=6.713 \times 10^{-8} \mathrm{P}^{0.641}$, where $\mathrm{q}$ is the flow rate in $\mathrm{m}^{3} \mathrm{~s}^{-1}$ and $\mathrm{P}$ is the pressure in $\mathrm{kPa}$.

Comparing Eqs. 5 and 15 and performing the necessary transformations allowed the calculation of maximum length for the zero-slope lateral line using Eq. 17:

$$
\mathrm{L}_{\max }=\left[\frac{(\mathrm{m}+1) \mathrm{h}_{\mathrm{falld}} \mathrm{S}_{\mathrm{e}}^{\mathrm{m}}}{\mathrm{aq}_{\text {mean }}^{\mathrm{m}} \mathrm{H}_{\mathrm{o}}^{-\mathrm{s}}}\right]^{\frac{1}{\mathrm{~m}+1}}
$$

where:

$\mathrm{L}_{\max }$ - maximum length of lateral line, $\mathrm{m}$;

$\mathrm{h}_{\mathrm{f} \text { alld }}$ - maximum head loss allowed along the lateral line, $\mathrm{m}$;

$\mathrm{S}_{\mathrm{e}} \quad$ - spacing between pairs of orifices, $\mathrm{m}$;

$\mathrm{q}_{\text {mean }}$ - mean flow rate of the pairs of orifices, $\mathrm{m}^{3} \mathrm{~s}^{-1}$;

$\mathrm{H}_{\mathrm{o}} \quad$ - pressure head at the lateral line inlet, $\mathrm{m}$;

a - coefficient of adjustment of Eq. 3;

$\mathrm{m}$ - exponent of flow rate in the head loss equation; and,

$s \quad$ - exponent of pressure head in Eq. 3.

For each maximum length, the uniformity of emission of the lateral line was obtained considering only hydraulic effects $\left(\mathrm{UE}_{\mathrm{h}}=\mathrm{q}_{\text {min }} / \mathrm{q}_{\text {mean }}\right)$, whose value must be higher than $95 \%$ to indicate possibility of a uniform irrigation (Barragan et al., 2006; Frizzone et al., 2012).

\section{Results AND Discussion}

In the analysis of head loss in the pipe without orifices, at each one of the six pressure heads tested, fitted equations were obtained to calculate head loss $\left(\mathrm{J}, \mathrm{m} \mathrm{m}^{-1}\right)$ as a function of flow rate in $\mathrm{m}^{3} \mathrm{~s}^{-1}$ (Table 1 ), and $\mathrm{R}^{2}$ values $\geq 0.998$ were obtained in the fitting. These equations reveal reduction of head loss in the pipe with the increase in pressure head, which indicates an increment in internal diameter. The coefficient $k_{2}$ (Eq. 2) decreases at mean rate of $2344.4 \mathrm{~s}^{2} \mathrm{~m}^{-6}$ for every $1 \mathrm{~m}$ increase in the pressure head. Significant increases in the diameter of flexible polyethylene pipes with the increase in operating pressure were observed and studied by Frizzone et al. (1998), Vilela et al. (2003), Rettore Neto et al. (2014) and Provenzano et al. (2016).

Table 1. Equations of head loss $\left(\mathrm{m} \mathrm{m}^{-1}\right)$ as a function of flow rate $\left(\mathrm{m}^{3} \mathrm{~s}^{-1}\right)$, for the Santeno I pipe

\begin{tabular}{cccc}
\hline $\begin{array}{c}\text { Inlet pressure } \\
(\mathrm{kPa})\end{array}$ & $\begin{array}{c}\text { Flow rate interval } \\
\left(\mathbf{m}^{3} \mathbf{s}^{-1}\right)\end{array}$ & $\begin{array}{c}\text { Head loss equation } \\
\left(\mathbf{m ~ m}^{-1}\right)\end{array}$ & $\mathbf{R}^{2}$ \\
\hline 49.0 & $0.62 \times 10^{-3}-1.43 \times 10^{-3}$ & $\mathrm{~J}=60670.35 Q^{2}$ & 0.9999 \\
58.8 & $0.64 \times 10^{-3}-1.45 \times 10^{-3}$ & $\mathrm{~J}=60031.98 Q^{2}$ & 0.9997 \\
68.6 & $0.63 \times 10^{-3}-1.45 \times 10^{-3}$ & $\mathrm{~J}=57850.45 Q^{2}$ & 0.9977 \\
78.4 & $0.62 \times 10^{-3}-1.45 \times 10^{-3}$ & $\mathrm{~J}=54113.44 Q^{2}$ & 0.9997 \\
88.2 & $0.63 \times 10^{-3}-1.44 \times 10^{-3}$ & $\mathrm{~J}=53484.28 Q^{2}$ & 0.9997 \\
98.0 & $0.60 \times 10^{-3}-1.45 \times 10^{-3}$ & $\mathrm{~J}=48935.24 Q^{2}$ & 0.9991 \\
\hline
\end{tabular}


The experimental data of head loss $\left(\mathrm{J}, \mathrm{m} \mathrm{m}^{-1}\right)$ were also fitted as a function of flow rate $\left(\mathrm{Q}, \mathrm{m}^{3} \mathrm{~s}^{-1}\right)$ and inlet pressure $\left(\mathrm{H}_{\mathrm{o}}, \mathrm{m}\right)$, obtaining Eq. 18 with root mean square error (RMSE) of 0.00197. According to Ali \& Abustan (2014), RMSE must tend to zero to indicate a good fit.

$$
\mathrm{J}=97265.791 \mathrm{Q}^{2} \mathrm{Ho}^{-0.279} \quad \mathrm{R}^{2}=0.9856
$$

where:

$\mathrm{J} \quad$ - unit head loss, in $\mathrm{m} \mathrm{m}^{-1}$;

$\mathrm{Q}$ - flow rate, in $\mathrm{m}^{3} \mathrm{~s}^{-1}$; and,

$\mathrm{H}_{\mathrm{o}} \quad$ - pressure head at the pipe inlet, in $\mathrm{m}$.

Figure 1 presents the agreement between the head losses observed in the tests and those estimated by Eq. 18, experimentally fitted. For the data set used, it can be noted that the pairs of points are well distributed around the 1:1 line. The estimates show good precision, with high Pearson correlation coefficient $(r=0.9856)$ (Ali \& Abustan, 2014) and good accuracy, with high Willmott's index of agreement (d=0.9887) (Wilmott, 1981).

The cumulative frequency distribution of the relative errors found in the adjustment of the model revealed that $95 \%$ of the estimates showed relative errors of up to $6.5 \%$. Relative errors of up to $5 \%$ occurred with frequency of $92 \%$. The low values of relative errors reveal good prediction ability of the model.

Comparing the Darcy-Weisbach equation, with $\mathrm{f}$ calculated by Eq. 8, and the Eq.18 leads to Eq.19.

$$
6.823 \times 10^{-4} \frac{\mathrm{Q}^{1.75}}{\mathrm{D}^{4.75}}=97265.791 \mathrm{Q}^{2} \mathrm{H}_{\mathrm{o}}^{-0.279}
$$

from which pipe diameter (D) was expressed as a function of the inlet pressure head $\left(\mathrm{H}_{\mathrm{o}}\right)$ and flow rate $(\mathrm{Q})$ (Eq. 20):

$$
\mathrm{D}=\left(7.015 \times 10^{-9} \mathrm{Q}^{-0.25} \mathrm{H}_{\mathrm{o}}^{0.279}\right)^{\frac{1}{4.75}}
$$

Eq. 20 was used to calculate the mean internal diameters of the pipe as a function of the inlet pressures for the interval of experimental flow rates, establishing the power-law relation between mean internal diameter $\mathrm{D}(\mathrm{m})$ and the inlet pressure head $\mathrm{H}_{\mathrm{o}}$ (m) (Eq. 21).

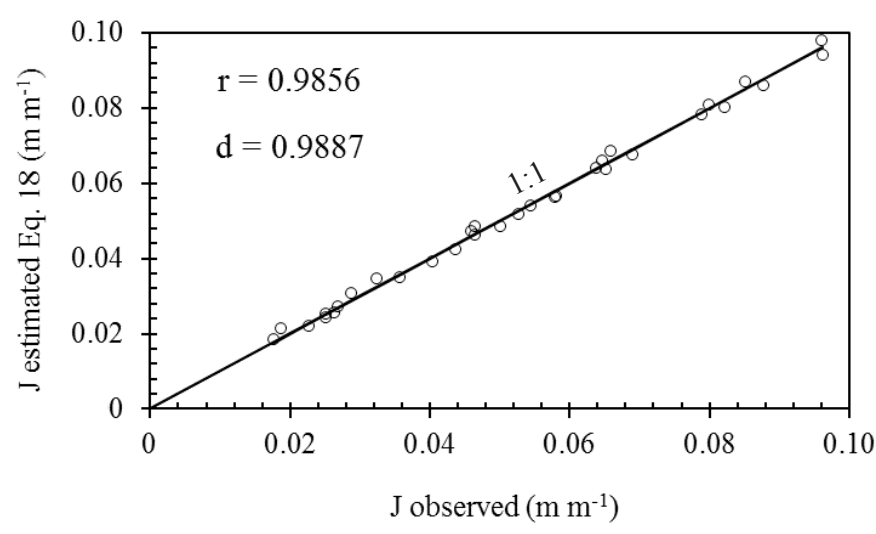

$\mathrm{r}$ - Correlation coefficient; $\mathrm{d}$ - Willmott's index

Figure 1. Agreement between head losses observed and head losses calculated by the fitted equation (Eq. 18)

$$
\mathrm{D}=27.2 \times 10^{-3} \mathrm{H}_{\mathrm{o}}^{0.0658} \quad \mathrm{R}^{2}=0.9529
$$

Andrade (1990), Frizzone et al. (1998) and Vilela et al. (2003) also found increase in the internal diameter of polyethylene pipes with the increase in operating pressure, according to a power-law relationship. Even at the operating pressure head of $50 \mathrm{kPa}$, the internal diameter estimated for the pipe $(0.0302 \mathrm{~m})$ is greater than the mean diameter informed by the manufacturer $(0.028 \mathrm{~m})$.

If the parameters of Eq. 21 are entered in Eq.10, the head loss for the Santeno pipe can also be expressed, alternatively, by the Darcy-Weisbach equation with friction factor calculated by Eq. 8 and diameter adjusted as a function of inlet pressure (Eq. 22):

$$
\mathrm{J}=18611.144 \mathrm{Q}^{1.75} \mathrm{H}_{\mathrm{o}}^{-0.313}
$$

Figure 2 shows the agreement between unit head losses observed and head losses calculated by Eq. 22, for a set of values of flow rate and inlet pressure head. It can be seen an acceptable adherence between the calculated and observed unit head losses $(r=0.9132$ and $d=0.8898)$. For the observed J values lower than approximately $0.45 \mathrm{~m} \mathrm{~m}^{-1}$, the head losses were overestimated by Eq. 22, whereas for values higher than $0.058 \mathrm{~m} \mathrm{~m}^{-1}$, the head losses were underestimated. This fact may be associated with the uncertainties in the estimation of the relation $\mathrm{D}\left(\mathrm{H}_{\mathrm{o}}\right)$ and also in equation to estimate the friction factor. However, the values of $\mathrm{r}$ and $\mathrm{d}$ indicate that Eq. 22 can be a reasonable alternative to Eq. 18. The cumulative frequency distribution of the relative errors indicated that $95 \%$ of the estimates showed relative error of up to 13.5 and $75 \%$ of the estimates had relative errors lower than $5 \%$.

Table 2 presents an application of Eq. 18 in the calculation of the maximum length of lateral lines using Santeno I perforated pipes, at zero slope. Maximum variations in emitter flow rate $\left(\mathrm{q}_{\mathrm{var}}\right)$ of $4,6,8$ and $10 \%$, and inlet pressures of $49.0,58.8,68.6$, $78.4,88.2$ and $98.0 \mathrm{kPa}$ were used. Eq. 17 was used with the following parameters of Eq. $18: \mathrm{a}=97265.791 ; \mathrm{s}=0.279, \mathrm{~m}=$ 2 and $\mathrm{S}_{\mathrm{e}}=0.15 \mathrm{~m}$.

It can be observed that the maximum length was not sensitive to the inlet pressure head, but decreased with the

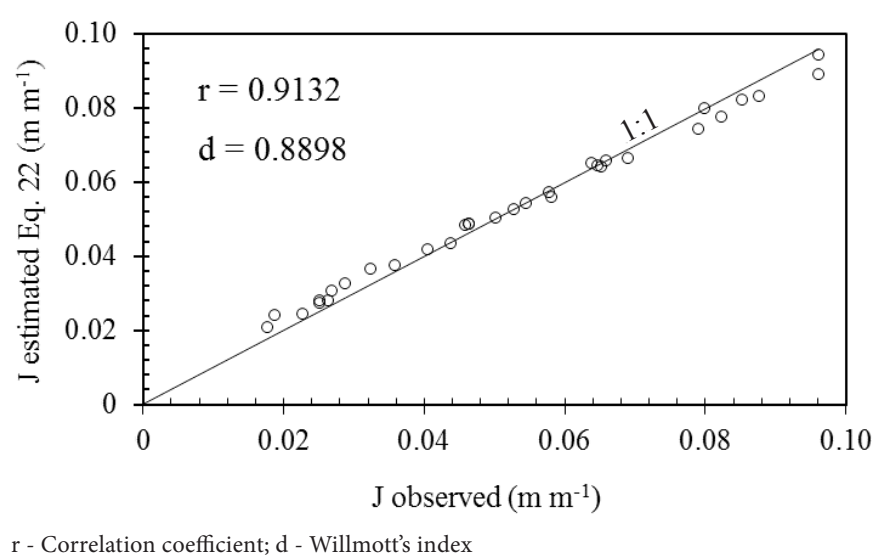

Figure 2. Comparison between unit head losses observed and calculated by the Darcy-Weisbach equation with diameter expressed by a power-law function of the inlet pressure head (Eq. 22) 
Table 2. Maximum length of lateral lines $(\mathrm{m})$ as a function of inlet pressure $(P)$ and variation of emitter flow rate $\left(q_{v a r}\right)$ for the Santeno I pipe

\begin{tabular}{ccccc}
\hline $\mathbf{P}$ & \multicolumn{4}{c}{$\mathbf{q}_{\operatorname{var}}(-)$} \\
\cline { 2 - 5 }$(\mathbf{k P a})$ & $\mathbf{0 . 1 0}$ & $\mathbf{0 . 0 8}$ & $\mathbf{0 . 0 6}$ & $\mathbf{0 . 0 4}$ \\
\hline 49.0 & $113.3(97.2)$ & $104.3(97.8)$ & $93.9(98.4)$ & $81.4(99.0)$ \\
58.8 & $113.3(97.2)$ & $104.2(97.8)$ & $93.9(98.4)$ & $81.4(99.0)$ \\
68.6 & $113.2(97.2)$ & $104.2(97.8)$ & $93.9(98.4)$ & $81.3(99.0)$ \\
78.4 & $113.2(97.2)$ & $104.2(97.8)$ & $93.9(98.4)$ & $81.3(99.0)$ \\
88.2 & $113.2(97.2)$ & $104.2(97.8)$ & $93.9(98.4)$ & $81.3(99.0)$ \\
98.0 & $113.2(97.2)$ & $104.2(97.8)$ & $93.9(98.4)$ & $81.3(99.0)$ \\
\hline
\end{tabular}

Values between parentheses correspond to the emission uniformity due to hydraulic effects (\%)

reduction of $\mathrm{q}_{\mathrm{var}}$ according to the power-law relation Lmax = $259.49 \mathrm{q}_{\mathrm{var}}^{0.3605}$. Contrarily to the Santeno I pipe, Frizzone et al. (1998) observed increase in the maximum length of the zeroslope Rain-Tape drip tape, with the progress of inlet pressure head. It should be considered, however, that the authors used as dimensioning criteria the coefficient of variation of the flow rate along the lateral, the coefficient of variation of the pressure and the coefficient of variation of the manufacturing, besides a head loss reduction factor which varied with the pressure head in the pipe, differently from the criterion used in the present study, which was a simple range of flow rate variation.

The uniformity of emission due to hydraulic effects decreased with the increment in $\mathrm{q}_{\mathrm{var}}$, but in all cases reached values equal to or higher than $97.2 \%$, compatible with excellent uniformity of irrigation (Barragan et al., 2006). For these types of pipes, Andrade (1990) recommends inlet pressure in the lateral of $78.4 \mathrm{kPa}$ for allowing better characteristics of lateral water distribution in the irrigated area and for covering a larger area.

\section{Conclusions}

1. The head loss equation for hydraulically smooth turbulent flow regime as a function of flow rate and pressure head at the pipe inlet has good ability to estimate head loss in flexible pipes which have variations in the internal diameter with the variation in the pressure head.

2. For particular cases of inlet pressure, the equations presented in Table 1 can be used. For more general cases of dimensioning, as normally occurs, Eq. 18 can be reliably used. Eq. 22, for having higher estimation error, can only be a reasonable alternative to Eq. 18 .

3. The maximum length of laser-perforated polyethylene pipes was estimated based on the criterion of acceptable flow rate variation of the irrigation subunit and, for zero-slope lateral line, the obtained values almost did not vary as a function of the pressure head at the pipe inlet.

\section{Literature Cited}

Ali, M. H.; Abustan, I. A new novel index for evaluating model performance. Journal of Natural Resources and Development, v.4, p.1-9, 2014.

Andrade, D. V. Avaliação hidráulica de tubos flexíveis de polietileno perfurados a laser, utilizados na irrigação. Piracicaba: ESALQ/ USP, 1990. 147p. Dissertação Mestrado
Anyoji, H.; Wu, I. P. Statistical approach for drip lateral design. Transactions of the American Society of Agricultural Engineers, v.30, p.187-192, 1987. https://doi.org/10.13031/2013.30425

Barragan, J.; Bralts, V.; Wu, I. P. Assessment of emission uniformity for micro-irrigation design. Biosystems Engineering, v.93, p.8997, 2006. https://doi.org/10.1016/j.biosystemseng.2005.09.010

Bernuth, R. D. von; Wilson, T. Friction factors for small diameter plastic pipes. Journal of Hydraulic Engineering, v.115, p.183-192, 1989. https://doi.org/10.1061/(ASCE)0733-9429(1989)115:2(183)

Bombardelli, W. W. A.; Camargo, A. P. de; Lavanholi, R.; Araújo, A. C. S.; Talamini Júnior, M. V.; Frizzone, J. A. Projeto e validação de uma bancada de ensaios de perda de carga localizada. Irriga, v.edição especial, p.1-10, 2017.https://doi.org/10.15809/irriga.2017v1n1p1-10

Bralts, V. F.; Edwards, D. M.; Wu, I. P. Drip irrigations and design and evaluation based on the statistical uniformity concept. Advances in Irrigation, v.4, p.67-117, 1987. https://doi.org/10.1016/B9780-12-024304-4.50005-5

Cardoso, G. G. G.; Frizzone, J. A.; Rezende, R. Fator de atrito em tubos de polietileno de pequenos diâmetros. Acta Scientiarum. Agronomy, v.30, p.299-305, 2008.

Frizzone, J. A.; Freitas, P. S. L. de; Rezende, R.; Faria, M. A. de. Microirrigação: Gotejamento e microaspersão. Maringá: Eduem, 2012. 356p.

Frizzone, J. A.; Vieira, A. T.; Paz, V. P. da S.; Botrel, T. A. Caracterização hidráulica de um tubo gotejador. Revista Brasileira de Engenharia Agrícola e Ambiental, v.2, p.278-283, 1998. https://doi. org/10.1590/1807-1929/agriambi.v2n3p278-283

Juana, L.; Rodriguez-Sinobas, L.; Losada, A. Determining minor head losses in drip irrigation laterals. I: Methodology. Journal of Irrigation and Drainage Engineering, v.128, p.376-384, 2002. https://doi.org/10.1061/(ASCE)0733-9437(2002)128:6(376)

Lahiouel, Y.; Lahiouel, R. Evaluation of energy losses in pipes. American Journal of Mechanical Engineering, v.3, p.32-37, 2015.

Melo, V. G. M. L. de; Almeida, A. N. de; Camargo, A. P. de; Frizzone, J. A. Caracterização hidráulica de tubos de polietileno para irrigação perfurados a laser. Irriga, v.edição especial, p.102-109, 2017. https://doi.org/10.15809/irriga.2017v1n1p102-109

Perboni, A.; Frizzone, J. A.; Camargo, A. P. de; Pinto, M. F. Modelling head loss along emitting pipes using dimensional analysis. Engenharia Agrícola, v.35, p.442-457, 2015. https://doi. org/10.1590/1809-4430-Eng.Agric.v35n3p442-457/2015

Pinto, M. F.; Camargo, A. P. de; Rettore Netto, O.; Frizzone, J. A. Hydraulic characterization of porous pipes made of recycled automobile tires used in subsurface irrigation. Revista Brasileira de Engenharia Agrícola e Ambiental, v.18, p.1095-1101, 2014. https://doi.org/10.1590/1807-1929/agriambi.v18n11p1095-1101

Provenzano, G.; Alagna, V.; Autovino, D.; Juarez, J. M.; Rallo, G. Analysis of geometrical relationships and friction losses in smalldiameter lay-flat polyethylene pipes. Journal of Irrigation and Drainage Engineering, v.142, p.1-9, 2016. https://doi.org/10.1061/ (ASCE)IR.1943-4774.0000958

Provenzano, G.; Pumo, D. Experimental analysis of local pressure losses for microirrigation laterals. Journal of Irrigation and Drainage Engineering, v.131, p.525-532, 2004. https://doi. org/10.1061/(ASCE)0733-9437(2005)131:6(525)

Rettore Neto, O.; Botrel, T. A.; Frizzone, J. A.; Camargo, A. P. Method for determining friction head loss along elastic pipes. Irrigation Science, v.32, p.329-339, 2014. https://doi.org/10.1007/s00271014-0431-7 
Rocha, H. S. da; Marques, P. A. A.; Camargo, A. P. de; Frizzone, J. A.; Saretta, E. Internal surface roughness of plastic pipes for irrigation. Revista Brasileira de Engenharia Agrícola e Ambiental, v.21, p.143-149, 2017. https://doi.org/10.1590/1807-1929/agriambi. v21n3p143-149

Sadeghi, S. H.; Peters, R. T.; Lamm, F. R. Design of zero slope microirrigation laterals: Effect of the friction factor variation. Journal of Irrigation and Drainage Engineering, v.141, p.1-9, 2015. https://doi.org/10.1061/(ASCE)IR.1943-4774.0000905

Swamee, P. K.; Swamee, N. Full range pipe-flow equations. Journal of Hydraulic Research, v.45, p.841-843, 2007. https://doi.org/10. 1080/00221686.2007.9521821

Tanaka, M.; Girard, G.; Davis, R.; Peuto, A.; Bignell, N. Recommended table for the density of water between $0{ }^{\circ} \mathrm{C}$ and $40{ }^{\circ} \mathrm{C}$ based on recent experimental reports. Metrologia, v.38, p.301-309, 2001. https://doi.org/10.1088/0026-1394/38/4/3
Vilela, L. A. A.; Soccol, O. J.; Gervázio, E. S.; Frizzone, J. A.; Botrel, T. A. Alteração no diâmetro e na perda de carga em tubos de polietileno submetidos a diferentes pressões. Revista Brasileira de Engenharia Agrícola e Ambiental, v.7, p.182-185, 2003. https:// doi.org/10.1590/S1415-43662003000100030

Willmott, C. J. On the validation of models. Physical Geography, v.2, p.184-195, 1981. https://doi.org/10.1080/02723646.1981.10642213

$\mathrm{Wu}, \mathrm{I}$. P. An assessment of hydraulic design of micro-irrigation system. Agricultural Water Management, v.32, p.275-284, 1997. https:// doi.org/10.1016/S0378-3774(96)01270-X

Yildirim, G. An assessment of hydraulic design of trickle laterals considering effect of minor losses. Irrigation and Drainage, v.56, p.399-421, 2007. https://doi.org/10.1002/ird.303

Yildirim, G.; Ağiralioğlu, N. Comparative analysis of hydraulic calculation methods in design of microirrigation laterals. Journal of Irrigation and Drainage Engineering, v.130, p.201-217, 2004. https://doi.org/10.1061/(ASCE)0733-9437(2004)130:3(201) 